\title{
NIKAH SIRI DAN AKIBAT HUKUMNYA MENURUT UU PERKAWINAN
}

\author{
Edi Gunawan ${ }^{1}$
}

\begin{abstract}
ABSTRAK
Pernikahan siri, yang secara agama dianggap sah, pada kenyataannya justru memunculkan banyak sekali permasalahan yang berimbas pada kerugian di pihak perempuan . nikah siri sering diambil sebagai jalan pintas pasangan untuk bisa melegalkan hubungan nya, meski tindakan tersebut pada dasarnya adalah pelanggaran UU No. 1 Tahun 1974 tentang perkawinan. Tulisan ini berusaha mengungkap faktor-faktor apa saja yang melatarbelakangi seseorang melakukan pernikahan siri, disamping problem-problem dan dampak yang berimbas pada perempuan. Pada dasarnya pernikahan siri dilakukan karena ada hal-hal yang dirasa tidak memungkinkan bagi pasangan untuk menikah secara formal. Ada banyak faktor yang melatarbelakangi terjadinya pernikahan siri, yang menurut penulis, semua alasan tersebut mengarah kepada pernkahan siri dipandang sebagai jalan pintas yang lebih mudah untuk menghalalkan hubungan suami isteri. Problem yang menyertai pernikahan siri yang paling nyata adalah problem hukum khususnya bagi perempuan, tapi juga problem intern dalam keluarga, problem sosial dan psikologis yang menyangkut opini publik yang menimbulkan tekanan batin bagi perilaku, problem agama yang perlu mempertanyakan lagi keabsahan nikah siri yang akhir-akhir marak terjadi di Indonesia. Dampak pernikahan siri bagi perempuan adalah secara hukum, istri tidak dianggap sebagai isteri sah, tidak berhak mendapat wariasan jika suami meninggal, tidak berhak mendapat harga gono-gini bila terjadi perpisahan. Dampak tersebut juga belaku bagi anak kandung hasil pernikahan siri.
\end{abstract}

Kata kunci: Nikah Siri, Akibat Hukum, Undang-Undang Perkawinan

${ }^{1}$ Penulis adalah Dosen tetap pada jurusan Syariah STAIN Manado 


\section{A. Pendahuluan}

Perkawinan merupakan ikatan lahir batin antara laki-laki dan perempuan yang terinstitusi dalam satu lembaga yang kokoh dan diakui baik secara agama maupun secara hukum. Al-qur'an, secara normatif banyak menganjurkan manusia untuk hidup berpasang-pasangan yang bertujuan untuk mewujudkan keluarga yang bahagia dan tentram. Berkaitan dengan status perkawinan, Al-qur'an juga menyebut dalam suarah An-Nisa 4:21, bahwa perkawinan sebagai mitsaaqan galidhan, yakni sebuah ikatan yang kokoh. Ikatan tersebut mulai diakui setelah terucapnya sebuah perjanjian yang tertuang dalam bentuk ijab dan qabul. ${ }^{2}$

Salah satu kerangka awal untuk mendapatkan jaminan hukum dalam sebuah perkawinan adalah dengan mencatatkannya kepada instansi yang berwenang. Hal ini tidak hanya berlaki bagi orang yang beragama Islam saja, melainkan juga bagi mereka yang beragama Kristen, Katholik, Hindu maupun Budha.Sebagaimana tertuang dalam UU No. 22 tahun 1946 jo. UU No. 321954 tentang Pencatatan Nikah, Talak dan Rujuk (Penjelasan Pasal 1) juga dalam UU No. 1 tahun 1974 tentang perkawinan pasal 2 ayat 2, yang diperkuat dengan Inpres RI No.1 tahun 1991 tentang Kompilasi Hukum Islam Pasal 5 dan 6.

Dalam Hukum Islam, Hukum perkawinan merupakan salah satu aspek yang paling banyak diterapkan oleh kaum muslimin di seluruh dunia dibanding dengan hukum-hukum muamalah yang lain. ${ }^{3}$ Perkawinan adalah mitsaqan ghalidan, atau ikatan yang kokok yang dianggap sah bila telah memenuhi syarat dan rukun pernikahan. Berdasarkan Al-qur'an dan hadis, para ulama menyimpulkan bahwa ha-hal yang termasuk rukun pernikahan adalah calon suami, calon istri, wali nikah, dua orang saksi, ijab dan qabul. Kewajiban akan adanya saksi ini adalah pendapat Syafi'i, Hanafi dan Hanbali. ${ }^{4}$ Adapun syarat sahnya nikah, menurut Wahbah Zuhaili adalah antara suami Istri tidak ada hubungan nasab, sighat ijab qabul tidak dibatasi

\footnotetext{
${ }^{2}$ Syukri Fathudin AW dan Vita Fitria, Problematika Nikah Siri dan Akibat Hukummnya Bgai Perempuan, (Penelitian, 2008), h. 1.

${ }^{3}$ J.N.D Anderson, Hukum Islam di Dunia Modern (Yogyakarta: Tiara Wacana, 1994), h 46.

${ }^{4}$ Mahmud Yunus, Hukum Perkawinan Dalam Islam Menurut Mazhab Syafi'I, Hanafi, Maliki dan Hanbali (Jakarta: Hidakarya Agung, 1996), h. 18.
} 
waktu, adanya persaksian, tidak ada paksaan, ada kejelasan calon suami istri, tidak sedang ihram, ada mahar, tidak ada kesepakatan untuk menyembunyikan akad nikah salah satu calon mempelai tidak sedang menderita penyakit kronis, adanya wali. ${ }^{5}$

Melihat kriteria rukun maupun persyaratan nikah diatas, tidak ada penyebutan tentang pencatatan. Keberadaan saksi sianggap telah memperkuat keabsahan suatu perkawinan. Pihak-pihak terkait tidak bisa mengadakan pengingkaran akan akad yang sudah terjadi. Biasa jadi ini didasarkan pada pernikahann masa Rasulullah sendiri tidak ada yang dicatatkan. Dalam kitab fikih klasikpun tidak ada pembahasan tentang pencatatan pernikahan.

Muncul beberapa dugaan tentang alasan mengapa nikah siri dengan segala resioknya masih dijadikan sebagai alternatif. Dikalangan masyarakat yang awam hukum dan masyarakat ekonomi lemah, bisa dimungkinkan karena keterbatasan dana sehingga dengan rosedur yang praktis tanpa dipungut biaya, pernikahan bisa dilaksanakan. Bila dilihat dari aspek agama, ada kemungkinan karena khawatir melakukan dosa dan tesjebak dalam perbuatan maksiat, maka pernikahan dengan prosedur yang cepat dan dianggap sah telah memberikan ketenangan batin tersendiri.

\section{B. Pembahasan}

\section{Nikah Siri dalam Hukum Positif}

Sudah menjadi catatan sejarah, bahwa dari dulu kaum perempuan selalu ditempatkan dalam posisi yang tersubordinasi. Hal ini terjadi karena berbagai mitos yang memojokkan perempuan selalu dipertahankan, hingga menjadi semacam dogma yang mengakar pada masyarakat setempat . salah satu mitos tersebut adalah cerita tentang penciptaan perempuan dan keluarnya Adam dari Surga ke bumi. Hawa diciptakan dari tulang rusuk Adam, oleh karena itu fungsi diciptakannya adalah untuk melengkapi hasrat Adam, dan Hawalah penyebab jatuhnya Adam dari Surga ke bumi. Perempuan dianggap sebagai sumber godaan syetan, penyebab terjadinya tindakan pelecehan seksual, berbahaya dan membutuhkan control dari laki-laki. ${ }^{6}$ Mitos-mitos tersebut

\footnotetext{
${ }^{5}$ Wahbah Zuhaili, All-Fiqh al-Islam wa adillatuhu (Beirut, Dar-al-Fikr, 1989), h. 62.

${ }^{6}$ Nikki R Keddi, Women in Middle Eastern History, Shifting Boundaries in Sex and Gender (New Heaven: Yale University Press, 1991), h. 13.
} 
akan semakin kuat bila faktor agama turut berperan didalamnya , hingga eksistensi mitos sendiri akan terhapus dan justru terlegitimasi dengan unsur teologis.

Tidak hanya bagi kaum laki-laki, kaum perempuan sendiri merasa yakin dengan menempatkan diri pada posisi itu, dan beranggapan bahwa hal tersebut datangnya dari Tuhan. Sehingga batas-batas antara laki-laki dan perempuan semakin jelas baik dalam pandangan kosmos maupun secara struktur sosial. Kondisi semacam ini dalam perkembangannya semakin dikuatkan oleh penafsiran-penafsiran yang keliru terhadap teks-teks keagamaan, akibatnya, secara sosiologis memunculkan perilaku kekerasan terhadap perempuan.

Alqur'an sebagai rujukan prinspip masyarakat islam, pada dasarnya mengakui bahwa kedudukan laki-laki dan perempuan adalah sama ${ }^{7}$. Keduanya diciptakan dari satu nafs (living entity), dimana yang satu tidak memiliki keunggulan atas yang lain. Bahkan Alquran tidak menjelaskan secara tegas bahwa Hawa diciptakan dari tulang rusuk Adam sehingga kedudukan dan statusnya lebih rendah. Atas dasar itu, prinsip Al-Qur'an terhadap kaum laki-laki dan perempuan adalah sama, dimana hak istri diakui dan sederajat dengan hak laki-laki.

Disisi lain,pada dasarnya Alquran menganjurkan mencatatkan tentang sesuatu yang berhubungan dengan akad, namu oleh mayoritas fuqaha hal tersebut dianggap sebagai anjuran, bukan kewajiban. Hal itu untuk menjaga agar masing-masing pihak tidak lupa dengan apa yang sudah diakadkan. Pernikahan pada masa Rasul, tidak ada ketentuan pencatatan karena belum banyak kasus yang berkembang seputar problem pernikahan seperti halnya saat ini. Perkembangan zaman saat ini menuntut suatu penyelesaian yang tegas secara hukum dari berbagai problematika pernikahan. Oleh karenanya, keberadaan dua orang saksi dianggap belum cukup. Karena mobilitas manusia yang semakin tinggi dan menurut adanya bukti autentik. Meskipun secara hukum Islam tidak termasuk dalam syarat dan rukun nikah, pencatatan pernikahan merupakan bagian yang wajib guna menghindari kesulitan di

\footnotetext{
${ }^{7}$ Muhammad Assad, The Message of the Al-qur'an (Gibraltar, 1980), h. 933
} 
masa yang akan datang. ${ }^{8}$ Dalam Bab II pasal 2 UU No 1 Tahun 1974 tentang Perkawinan disebut dengan pencatatan perkawinan dengan berbagai tatacaranya, yaitu “ (1) Perkawinan adalah sah apabila dilakukan menurut hukum masing-masing agama dan kepercayaan itu, dan ayat (2) tiap-tiap perkawinan dicatat menurut peraturan perundang-undangan yang berlaku. Hal tersebut diperjelas dalam KHI (Kompilasi Hukum Islam) Pasal 5 (1) yang menyebutkan, "Agar terjamin ketertiban perkawinan bagi masyarakat Islam, setiap perkawinan harus dicatat.” Begitu juga dalam pasal 6 (2) ditegaskan bahwa "Perkawinan yang dilakukan diluar pengawasan pegawai pencatat nikah tidak mempunyai kekuatan hukum."

Dalam kenyataannya, praktek perkawinan yang terjadi di lingkungan masyarakat tidak sepenuhnya mengacu kepada Undang Undang. Beberapa proses perkawinan mengacu kepada lembaga masing-masing. Fakta ini harus diakui karena pengakuan negara terhadap pluralisme hukum tidak bisa diabaikan. Konsekuensinya pilihan hukum dalam bidang keluarga cenderung di serahkan sebagai kewenangan pribadi. Sebagai contoh, kasus nikah sirih adalah pilihan hukum yang didasarkan kepada konteks agama yang penekanan esensinyatidak sekedar hubungan hukum saja, tapi lebih kepada faktorkonsekuensi pengamalan ibadah kepada Allah.

Dari sinilah kemudian kasus nikah siri atau nikah dibawah tangan merebak menjadi fenomena tersendiri. Nikah siri adalah suatu pernikahan, meski telah memenuhi syarat dengan rukun nikah, tetapi karena alasan tertentu, tidak dicatatkan dikantor urusan agama. Secara hukum islam, pernikahan tersebut dinanggap sah oleh beberapa kalangan karena telah memenuhi kriteria keabsahan pernikahan yaitu adanya ijab, qabul, dua orang mempelai, wali dan dua orang saksi. Nikah siri masih sering dijadikan sebagai alternatif mengantisipasi pergaulan bebas antara laki-laki dan perempuan non muhrim yang secara psikologis, moril, maupun materiil belum mempunyai kesiapan untuk menikah secara formal.

Pernikahan adalah suatu proses hukum, sehingga hal-hal atau tindakan yang muncul akibat pernikahan adalah tindakan hukum yang mendapat

\footnotetext{
${ }^{8}$ Syukri Fathudin A. W dan Via Fitri, op., cit, h.3
} 
perlindungan secara hukum. Bila perkawinan tidak dicatatkan secara hukum, maka hal-hal yang berhubungann dengan akibat pernikahan tidak bisa diselesaikan secara hukum. Sebagai contoh, hak istri untuk mendapat nafkah lahir dan batin, akte kelahiran anak tidak bisa diurus, hak pengasuhan anak, hak pendidikan anak, hak waris istri, hak perwalian bagi anak perempuan yang akan menikah dan masih banyak problem-problem lain.

Kekerasan terhadap istri berasal dari banyak faktor yang pada dasarnya mengarah kepada dominasi konsep patriarkhi dalam masyarakat. Konsep tersbut diterjemahkan sebagai sebuah sistem dominasi laki-laki yang menindas perempuan melaluli institusi sosial, politik dan ekonomi. Kenyataannya adalah bahwa budaya patriakhi mengejawantah dalam bentukbentuk historis jenis apapun. Apakah itu dalam sistem feodal, kapitalis maupun sosialis. ${ }^{9}$

Meski sudah banyak diketahui bahwa pada prinsipnya nikah siri merugikan kaum perempuan, namun sampai saat ini fenomena tersebut masih sering dijumpai. Praktik nikah siri tersebut tidak hanya terjadi dilingkungan masyarakat yang awam hukum, berpendidikan rendah, atau golongan ekonomi menengah kebawah saja, tetapi juga banyak terjadi di lingkungan masyarakat terpelajar yang memahami hukum, ataupun di lingkungan masyarakat golongan menengah keatas yang secara ekonomi bisa dikatakan sangat mapan. Tidak jarang ditemui dikalangan masyarakat umum, mahasiswa, artis, ulama bahkan para pejabat.

Sebagaimana yang terjadi dalam kasus nikah siri, masih banyak kaum perempuan yang beranggapan bahwa nikah siri adalah suatu bentuk tanggung jawab moral kaum laki-laki yang bersedia melewati tahapan hubungan yang lebih serius untuk sesaat memang bisa dibenarkan, namun secra faktual proses pernikahan tersebut sangat tidak adil gender, mengingat kaum perempuan akan menuai banyak permasalahan di kemudian harinya. Sebaliknya, pihak laki-laki tidak menanggung beban, bahkan ketika dia lalai

\section{h.16.}

${ }^{9}$ Gadis Arivia, Filsafat Berspektif Feminis, (Jakarta: Yayasan Jurnal Perempuan, 2003), 
akan kewajibannya sebagai seorang suami (secara siri), tidak ada tuntutan hukum. ${ }^{10}$

Meninjau kembali keabsahan nikah siri secara Syar'i, akan berbenturan dengan maqashid asy-syariah atau tujuan diberlakukan hukum syariah. ${ }^{11}$ Ketika perkawinan dilakukan secara siri dan tanpa dicatatkan kepada pihak yang berwenang, secara agama, bila telah memenuhii rukun syarat pernikahan adalah sah. Dengan latar belakang khawatir terjadinya zina atau perbuatan lain yang melanggar syariat, maka pernikahan tersebut dikategorikan kedalam tujuan hifdz ad-din dan hifdzu an-nasl. Yang perlu dikaji lagi bahwa adalah tujuan tersebut hanya bisa terwujud sesaat setelah pernikahan berlangsung. Namunn dampak hukum dari perkawinandan akibat-akibat lain yang sering muncul dalam perkawinan akan muncul dalam rentang waktu panjang. Sementara maqashid al-syari'ah tidak ditujukan untuk ketenangan sesaat, tetapi antisipasi jangka panjang lebih diperhitungkan. ${ }^{12}$

Dalam ajaran agama apapun dan dalam etika sosial masyarakat dimanapun, semua umumnya sepakat bahwa kehadiran perempuan dan anak mutlak harus dilindungi dari semua bentuk ancaman perlakuan kasar serta tekanan psikis. Tetapi untuk memastikan agar perempuan tidak menjadi korbann yang dirugikan dalam lembaga dan kehidupan perkawinan dengan pasangannya, sebetulnya yang dibutuhkan bukan hanya nilai, norma, dan payung hukum yang pro-perempuan, tapi yang juga tak kalah penting adalah upaya-upaya ypenting yang lebih berorientasi pada pemberdayaan perempuan secara mandiri.

Mereduksi komitmen untuk melindungi perempuan dari kemungkinan menjadi korban dalam pernikahan siri, kawin kontrak atau yang lain dalam pasal-pasal ketentuan hukum harus siakui rawan terjebak kedalam sikap "hitam-putih" yang terkadang kurang mempertimbangkan situasi nyata di masyarakat. Tapi sikap yang menolak secara membabi-butadan seolah-olah menutup mata terhadap penderitaan sebagian perempuan yang menjadi

${ }^{10}$ Syukri Fathudin, Vita Fitria, op.cit, h. 10

11 Tujuan diberlakukannya hukum islam meliputi: 1). Menjaga jiwa (Hifz an-nafs), 2). Menjaga agama (Hifz ad-din), 3). Menjaga keturunan (Hifdz an-nasl), 4). Menjaga akal (Hifz alaql) dan 5). Menjaga harta (Hifdz al-mal). Lihat Abd. Wahab Khallaf, Ilmu Ushul Fiqh, terj. Moh. Zuhri dan Ahmad Qarib, (Semarang: Dina Utama, 1994). H. 313

${ }^{12}$ Syukri Fathudin dan Vita Fitria op.cit h. 11. 
korban dalam pernikahan siri dari laki-laki yang pragmatis dan sekadar melegitimasi syahwatnya belaka tentu juga bukan sikap yang bijak. ${ }^{13}$

\section{Faktor-Faktor yang Melatarbelakangi Terjadinya Pernikahan Siri}

Melihat kasus-kasus yang terjadi pada pernikahan Siri, masing-masing mempunyai latar belakang yang secara khusus berbeda, namun secara umum adalah sama yaitu ingin memperoleh keabsahan. Dalam hal ini yang dipahami oleh masyarakat adalah pernikahan siri sudah sah secara agama. Sebagian masyarakat masih banyak yang berpendapat nikah merupakan urusan pribadi dalam melaksanakan ajaran agama, jadi tidak perlu melibatkan aparat yang berwenang dalam hal ini Kantor Urusan Agama (KUA). Disamping itu pernikahan sirih juga dianggap sebagai jalan pintas bagi pasangan yang menginginkan pernikahan namun belum siap atau ada hal-hal lain yang tidak memungkinkannya terikat secara hukum.

Faktor-faktor yang melatar belakangi terjadinya pernikahan siri adalah: ${ }^{14}$

1. Nikah siri dilakukan karena hubungan yang tidak direstui oleh orang tua kedua pihak atau salah satu pihak. Misalnya orang tua kedua pihak atau salah satu pihak berniat menjodohkan anaknya dengan calon pilihan mereka.

2. Nikah siri dilakukan karena adanya hubungan terlarang, misalnya salah satu atau kedua pihak sebelumnya pernah menikah secara resmi tetapi ingin menikah lagi dengan orang lain.

3. Nikah siri dilakukan dengan alasan seseorang merasa sudah tidak bahagia dengan pasangannya, sehingga timbul niatan untuk mencari pasangan lain.

4. Nikah siri dilakukan dengan dalih menghindari dosa karena zina. Kekhawatiran kekhawatiran tersebut banyak dialami oleh pasangan mahasisawa. Hubungan yang semakin hari semakin dekat, menimbulkan kekhawatiran akan terjadinya perbuatan yang melanggar syariah. Pernikahan siri dianggap sebagai jalan keluar yang mapu mengahalalkan gejolak cinta sekaligus menghilangkan kekhawatiran tejadinya zina.

\footnotetext{
${ }^{13}$ Bagong Suyanto, “Nikah Siri, Bagaimana Menyikapinya?”, Majalah Tempo, Tanggal 24 februai 2010

${ }^{14}$ Syukri Fathudin dan Vita , op.cit, h. 26
} 
5. Nikah siri dilakukan karena pasangan merasa belum siap secara materi dan secara sosial. Hal ini biasa dilakukan oleh para mahasiswa, disamping khawatir karena terjadi zina, mereka masih kuliah, belum punya persiapan jika harus terbebani masalah rumah tangga. Status pernikahan pun masih disembunyikan supaya tidak menghambat pergaulan dan aktivitas dengan teman-teman dikampus.

6. Nikah siri sering ditempatkan sebagai sebuah pilihan ketika seseorang hendak berpoligami dengan sejumlah alasannya tersendiri. Seperti contohcontoh kasus berikut: a) Pujiono menikahi Ulfa yang masih dibawah umur, sebagai istri kedua. Yang menjadi kontroversial adalah usia Ulfa masih 12 tahun. Dengan dalih sah secara agama, dan berpedoman kepada pernikahan Rasul dan Aisyah yang masih berumur 9 tahun, pernikahan tersebut berlangsung bahkan dengan persetujuan orang tua Ulfa dan istri pertama Pujiono. Namun karena sorotan dari berbagai kalangan, Pujiono akhirnya mengembalikan Ulfa kepada orang tuanya. b) Pernikahan yang pernah terjadi antara Rhoma Irama dengan Angel Lelga yang menurut beberapa sumber media, Rhoma menikahi Angel karena dia bersedia menjadi Muallaf. Pernikahan tersebut ditutupi salah satunya karena khawatir popularitas keartisannya akan pudar. Nyatanya, setelah terekspos media masa, Rhoma Irama justru menceraikan Angel Lelga. c) Pernikahan Bambang Triatmojo dan Mayangsari. Sebagai orang terkenal di Indonesia, pernikahan siri dalam poligami yang dilakukan Bambang salah satunya bertujuan mengindari publikasi media. Ketika pers mengulas berita tersebut, yang terjadi adalah konflik berkepanjangan dengan istri pertamanya, Halimah bahka dengan anak-anaknya. Disinilah sebenarnya keabsahan nikah siri haru dipertanyakan kembali.

7. Nikah siri dilakukan karena pasangan memang tidak tahu dan tidak mau tahu prosedur hukum. Hal ini bisa terjadi pada suatu masyarakat wilayah desa terpencil yang jarang bersentuhan dengan dunia luar. Lain lagi dengan komunitas jamah tertentu misalnya, yang menganggap bahwa kyai atau pemimpin jamaah adalah rujukan utama dalam semua permasalahan termasuk urusan pernikahan. Asal sudah dnikahkan oleh kyainya, pernikahan sudah sah secara Islam dan tidak perlu dicatatkan. 
8. Nikah siri dilakukan hanya untuk penjajakan dan menghalalkan hubungan badan saja. Bila setelah menikah ternyata tidak ada kecocokan maka akan mudah menceraikannya tanpa harus melewati prosedur yang berbeli-belit di persidangan. Dilihat dari tujuannya, hal ini sangat merendahkan posisi perempuan yang dijadikan objek semata, tanpa ada perngahrgaan terhadap lembaga pernikahan baik secara Islam maupun secara hukum.

9. Nikah siri dilakukan untuk menghindari beban biaya dan prosedur administrasi yang berbelit-belit. Biasanya pernikahan semacam ini dilakukan oleh kalangan pendatang yang tidak mempunyai KTP. Disamping alasan biaya, alasan administrasi juga menjadi kendalanya.

10. Nikah siri dilakukan karena alasan pernikahan beda agama. Biasanya salah satu pasangan bersedia menjadi muallaf (masuk Islam) untuk memperoleh keabsahan pernikahannya.

11. Dan masih banyak faktor-faktor lain, semua alasan tersebut mengarah kepada posisi perkawinan siri dipandang sebagai jalan yang lebih mudah untuk menghalalkan hubungan suami istri.

\section{Dampak Hukum Nikah Siri}

Pernikahan merupakan perbuatan hukum, jadi segala sesuatu yang ditimbulkan akibat pernikahan adalah sah secara hukum. Mengingat pernikahan siri cacat secara hukum, maka tidak ada perlindungan hukum bagi suami, istri maupun anak. Problem-problem yang muncul mayoritas adalah problem hukum yang mungkin tidak pernah dibayangkan ketika seseorang pertama kali memutuskan untuk menikah siri. Dalam hal ini istri adalah pihak yang paling dirugikan sedangkan suami hampir tidak memiliki kerugian apaapa.

Pada dasarnya dalam setiap perkawinan selalu akan muncul problem yang menyertai. Sejauh perkawinan itu sah secara hukum. Sebut saja pernikahan antara Syekh Puji dengan Ulfa. Dengan dalih sah secara agama, seorang laki-laki bebas untuk menikahi perempuan manapun yang ia mau, bahkan bila harus berbenturan dengan hukum positif dimana dia tinggal. Apalagi bilak posisi laki-laki tersebut adalah tokoh agama yang mempunyai banyak santri, calon istri yang dinikahi merasa terangkat status sosialnya. Namun bagaimana dengan lingkungan dan masyarakat sekitar yang merasa 
terganggu dengan keputusan tersebut? Bagaimana dengan UU perkawinan yang sudah diabaikan, ditambah pengabaian terhadap UU Perlindungan Anak, perlindungan terhadap hak kesehatan reproduksi perempuan dan sebagainya. Seorang anak usia 12 tahun, seharusnya diberi kesempatan untuk berkembang dan menikmati masa menjelang remaja sebagaimana anak-anak seusianya. Kesehatan reproduksinya masih belum memungkinkan untuk diperlakukan sebagaimana perempuan dewasa, yang bila tidak diperhatikan tentunya rawan terhadap berbagai penyakit yang berhubungan dengan organ kewanitaan. ${ }^{15}$

Problem-problem diatas hanya sebagian kecil dari banyak kasus-kasus pernikahan siri yang lain. Harus diakui bahwa pernikahan siri rawan sekali terhadpa konflik, baik konflik internal dalam rumah tangga maupun konflik eksternal yang berhubungan dengan hukum dan masyarakat. Problemproblem tersebut diantaranya adalah :

1. Problem keluarga. Konflik dalam keluarga ini bisa muncul bila :

a) Pernikahan siri yang dilakukan tidak atas persetujuan orang tua atau sebaliknya, paksaan daari orang tua.

b) Perselingkuhan. Nikah siri yang terjadi kaena perselingkuhan biasanya memunculkan problem keluarga yang lebih rumit. Problem dengan istrinya yang sah tentu tidak bisa dianggap sepele. Seperti kasus Bambang Triatmojo dan Mayangsari adalah adalah kasus pernikahan siri yang berbuntut panjang. Bagaimana Mayangsari harus bertahan dari tekanan pihak istri dan anak-anaknya yang sah. Sementara dia sendiri sebenarnya butuh dukungan, perhatian, dan butuh kekuatan untuk tetap bisa eksis di tengah-tengah penilaian negatif masyarakat terhadap dirinya. Ini merupakan gambaran yang sangat kontras dengan kondisi pernikahan siri ketika pertama kali dilangsungkan, dengan tujuan menghindarri zina, ketenangan batin dan tujuan-tujuan mulia yang lain. ${ }^{16}$

c) Poligami. Pernikahan siri yang terjadi di Indonesia akhir-akhir ini identik dengan perselingkuhan dan poligami. Masyarakatpun seakan tidak bisa memahami bahwa perempuan adalah perempuan adalah

${ }^{15}$ Syukri Fathudin dan Vita Fitria, op.cit h. 29.

${ }^{16}$ Ibid. H. 31. 
korban dan butuh dilindungi. Yang trjadi justru sebaliknya, prasangka dan pandangan negatif justru lebih banyak ditujukan kepada pihakk perempuan daripada pihak laki-laki.

d) Beda Agama. Pernikahan siri sendiri adalah pelanggaran terhadap hukum positif. Bila dilakukan karena alasan beda agama, misal salah satu ingin menjadi muallaf tapi belum siap secara kaffah, maka permasalahan yang muncul adalah status anak dan benturan dengan hukum positif. Bila seseorang menjadi muallaf hanya untuk melegalkan pernikahan secara islam saja, maka keabsahan pernikahannya dipertanyakan. Problem akan muncul pada anak-anak ketika melewati tahap perkembangan. Bagaimana seorang anak harus memilih agama orang tuanya yang berbeda. Lebih parah lagi kalauu anak tersebut tidak bisa memilih dan akhirnya tidak memiliki konsep aqidah yang jelas. ${ }^{17}$

\section{Problem Ekonomi dan Studi}

Problem ekonomi ini biasanya menyertai para mahasiswa yang tanpa sepengetahuan atau tanpa persetujuan orang tua melakukan nikah siri. Mereka haru mencari biaya sendiri untuk mencukupi kebutuhan hidup sehari-hari. Ditengah aktivitasnya sebagai mahasiswa, dia harus bisa membagi waktu untuk kuliah, pekerjaan dan keluarga barunya. Hal ini tentu akan berimbas pada studinya yang tidak lancar, bahkan terhenti karena pernikahan yang dilakukan cukup menyertakan problem-problem yang serius.

\section{Problem Hukum}

Nikah siri adalah pelanggaran hukum. Kalau saja pemerintah bisa lebihh tegas lagi, maka para pelaku nikah siri bisa dikenakan sanksi hukum. Problem hukum dalam pernikahan siri terjadi pada pihak perempuan dan anak. Sebagai istri yang sah secara agama, istri tidak bisa menuntuk hak nafkah lahir batin hak waris bila terjadi perceraian, hak pengaduan bila terjadi kekerasan dalam rumah tangga, atau hak perlindungan hukum bila ditinggal pergi tanpa pesan. Posisi suami yang tidak tersentuh hukum,

\footnotetext{
${ }^{17}$ Ibid, h. 32 .
} 
memunculkan ruang yang lebar bagi terjadinya kekerasan dalam rumah tangga yang yang dilakukan oleh suami terhadap istri. Kekerasan tersebut banyak dijumpai entah dalam bentuk kekerasan fisik, psikhis, ekonomi maupun kekerasan seksual. Pernikahan ini sangat menguntungkan pihak suami , karena a). Suami bebas untuk menikah lagi , karena pernikahannya dianggaptidak pernah ada secara hukum, b). Suami bisa berkelit dan menghindar dari kewajibannya memberi nafkah kepada isteri dan anakanak, c). Suami tidak dipusingkan dengan pembagian harta gono-gini, warisan, hak nafkah istri maupun hak nafkah dan hak pendidikan anak ketika terjadi perceraian. ${ }^{18}$

\section{Problem Sosial dan Psikologis}

Hidup serumah tanpa bisa menunjukan surat nikah resmi merupakan hal yang tidak semua orang bisa memaklumi. Masyarakat akan mempertanyakan, mengapa harus menikah siri, mengapa harus sembunyi sembunyi? Dan pertanyaan-pertanyaan tersebut akan merebak membawa image negatif bagi perempuan pelaku nikah siri. Hamil dulu kah? Perempuan simpanankah? Tidak disetujui orangtua? Dan bermacammacam prasangka lain yang memicu pergunjingan di kalangan masyarakat. Para perangkat desa sejujurnya juga kesulitan untuk mendata status keluarga tersebut karena bukti tertulis tidak bisa ditunjukan. Kondisi ini bisa menyebabkan sulit beradaptasi dengan lingkungan, sulit terbuk karena pernikahannya dilakukan secara tidak formal, dan akhirnya bisa terisolasi dari lingkungan, yang akan berdampak pada kondisi psikhis terutama perempuan. Baik itu pernikahan siri yang dilakukan oleh masyarakat awam atau pun publik figur. Semua contoh kasus nikah sirih diatas menyisakan problem sosial. Hanya saja kadar tekanan dari masyarakat berbeda. Kasus syekh puji mungkin yang paling menghebohkan, karena semua pihak turut tangan. Komnas Perlindungan Anak adalah yang paling berupaya keras menghalangi pernikahannya. Sayangnya, tidak ada cendikiawan muslim, alim ulama maupun tokoh agama yanag bisa memberi penjelasan tentang makna nikah siri yang sesungguhnya. Melihat

\footnotetext{
${ }^{18}$ Ibid, 34.
} 
kondisi tersebut, pada akhirnya justru melicinkan anggapan masyarakat bahwa pernikahan seiri merupakan alternatif tercepat untuk melegalkan hubungan suami istri.

\section{Problem Agama}

Pernikahan siri dalam poligami yang dilakukan oleh A'a Gym, Rhoma Irama maupun publik figur justru menguatkan anggapan masyarakat bahwa nikah sirih adalah alternatif yang dilakukan bila seseorang ingin melakukan hubungan suami isteri secara halal atau untuk berpoligami. Mengingat banyak sekali dampak negatifnya, peran tokoh agam a seharusnya adalah memmberi pengertian bahwa pernikahan siri bukan hal yang positif terutama yang kaum perempuan. Yang terjadi justru pernikahan siri dilakukan oleh pemuka agama. Di sinilah sebenarnya nikah sirih meski sah secara agama, namun menjadi problem agama tersendiri yang harus segera dicari penyelesaiannya. Nikah sirih memang sah secara Islam, namun dampak negatifnya jauh lebih banyak daripada ketenangan batin yang didapat. Fenomena yang terjadi sekarang adalah nikah sirih ditempuh oleh berbagai kalangan terkesan hanya ingin mencari solusi atas hasrat seksualnya yang sudah tidak terbendung. Kalau opini negatif masyarakat tentang nikah sirih sudah terbentuk seperti ini, bukankah ini sama saja dengan opini negatif terhadap Islam. Disinilah pernikahan sirih yang keabsahannya secara agama justru mendatangkan mudhharat yang lebih besar.

\section{Kesimpulan}

1. Nikah siri menurut hukum positi adalah Perkawinan yang dilakukan tidak sesuai dengan UU No. 1 Tahun 1974 tentang perkawinan. Pada peraturan perundang-undangan tersebut menyebutkan bahwa perkawinan adalah sah apabila dilakukan menurut hukum masing-masing agama dan kepercayaannya itu, dan tiap-tiap perkawinan dicatat menurut peraturan perundang-undangan yang berlaku.

2. Faktor-faktor yang melatarbelakangi terjadinya pernikahan siri antara lain; nikah sirih dilakukan karena hubungan yang tidak direstui oleh orang tua kedua pihak atau salh satu pihak, karena adanya hubungan terlarang, 
seseorang merasa sudah tidak bahagia dengan pasangannya, sehingga timbul niatan untuk mencari pasangan lain, menghindari dosa (zina), pasangan merasa belum siap secara materi dan secara sosial, tidak mendapat izin dalam berpoligami, pasangan tidak tahu dan tidak mau tahu prosedur hukum, untuk penjajakan dan menghalalkan hubungan badan saja, untuk menghindari beban biaya dan prosedur administrasi yang berbelitbelit, karena alasan nikah beda agama, dan masih banyak faktor lain.

3. Dampak hukum yang bisa timbul dari pernikahan siri, antara lain; dapat menimbulkan konflik dalam keluarga, misalnya karena tidak direstui, nikah beda agama, poligami dan lain sebagainya, dampak ekonomi dan pendidikan, hal ini biasanya dilakukan oleh mahasiswa, dampak hukum yaitu pernikahan siri adalah sebuah pelanggaran hukum, problem sosial dan psikologis serta dampak pada agama, misalnya pernikahan sirih yang dilakukan oleh ustazd atau kyai. 


\section{DAFTAR PUSTAKA}

Anderson J.N.D Hukum Islam di Dunia Moder, Yogyakarta, Tiara Wacana, 1994.

Arivia Gadis, Filsafat Berperspektif Feminis, Jakarta; Yayasan Jurnal Perempuan, 2003

Assad Mohammad, The Message of the Al-Qur'an, Gilblartar; 1980.

Fathudin AW Syukri dan Vita Fitria, Problematika Nikah Siri dan Akibat Hukumnya Bagi Perempuan, Penelitian, 2008.

Keddie R Nikki, Women in Middle Eastern History, Shifting Boundaries in Sex and Gender, New Heaven, Yale University Press, 1991.

Khallaf Wahab Abdul, Ilmu Ushul Fiqh, ter. Moh.Zuhri dan Ahmad Qarib, Dina Utama, Semarang, 1994.

Suyanto Bagong, Nikah Siri, Bagaimana Menyikapinya ?. Majalah Tempo, Tanggal 24 Februari 2010.

Yunus Mahmud, Hukum Perkawinan Dalam Islam Menurut Mazhab Syafi'i, Hanafi, Maliki, dan Hambali, Jakarta, Hidakarya Agung, 1996.

Zuhaili Wahbah, All- Fiqh al-Islam wa adillatuhu, Beirut, Dar- al-Fikr, 1989. 